\title{
On some problems of the legal regime of unauthorized construction objects
}

\author{
Vera Kudryavtseva ${ }^{1, *}$, and Natalia Vasileva $^{2}$ \\ ${ }^{1}$ Irkutsk National Research Technical University, 664074, 83 Lermontova str., Irkutsk, Russia \\ ${ }^{2}$ Saint-Petersburg State University of Economics, 191023, Sadovaya str., 21, St. Petersburg, Russia
}

\begin{abstract}
In real socio-economic conditions, unauthorized construction is a phenomenon quite common in contemporary society. Construction remains the main type of land use and planning of the populated areas, especially in the prevailing conditions, when every year the population in large cities of Russia is growing, which leads to a steady expansion of borders and an increase in the area occupied by cities. At the same time, in the absence of a clear, proper urban planning, and the development of urban and rural settlements, the number of buildings being built illegally will increase. In order to prevent the growth of the number of such construction projects, there is a clear legal framework that regulates the concept and consequences of unauthorized actions to create or change real estate objects. When carrying out repairs, modernization, reconstruction, or construction of real estate objects, certain conditions and approvals are required; otherwise, the building can be recognized as unauthorized and become subjected to further liquidation. In order to reduce the practice of unauthorized construction and reduce corruption risks, it is necessary to toughen the interpretation of the concept of unauthorized construction and through the introduction of an unambiguous civil law regulation, especially in the conditions of securing ownership over the objects of such origin.
\end{abstract}

\section{Introduction}

For Russia, the phenomenon of erecting objects being unauthorized constructions is far from rare. A large number of such objects appeared on the territory of the country even during the military or post-war period. Unfortunately, at present, cases of unauthorized construction are also common, despite the rapid development of legislative norms and legal regulation with regard to the construction of capital construction projects. In this regard, the answer to the question of whether the erected building is unauthorized, in real socio-economic conditions, is quite relevant.

\footnotetext{
*Corresponding author: kudravera@mail.ru
} 


\section{Materials and methods}

In order to correctly identify the existing approaches to solving the problem of unauthorized construction on the territory of the Russian Federation, it is, first of all, necessary to disclose the content of the very concept "unauthorized construction", enshrined in the Civil Code of the Russian Federation.

Art. 222 of the Civil Code of the Russian Federation gives the following definition: "An unauthorized construction is a building or other structure erected on a land plot not provided in accordance with the established procedure or on a land plot, the permitted use of which does not permit the construction of a given object on it, or erected, created without obtaining necessary permits or with violation of town-planning and building norms and rules" [1]

At the same time, it should be noted that this article is in Chapter 14 of the Civil Code of the Russian Federation, which deals with the acquisition of property rights. This circumstance may indicate that, according to the current legislation, unauthorized construction is only one way of acquiring property rights to real estate. But at the same time, the person who carried out the construction, after it is completed, does not have ownership of the erected building. Accordingly, such a construction cannot function properly in the market, because it cannot be presented, sold, or exchanged.

In accordance with the current regulatory framework, the emergence of ownership over an unauthorized construction is directly dependent on the type of rights to a land plot. For the recognition of an unauthorized construction as legal and, as a result, the acquisition of ownership over it, it is necessary that the land on which it is erected should be belong to the person wishing to obtain the rights to this building:

- in the property;

- indefinite use;

- lifelong possession.

The review of different views on identifying the subjects of relations governed by Article 222 of the Civil Code of the Russian Federation is, as a result, reduced to one opinion, namely that these subjects of relations are clearly and specifically defined in legislation (Figure 1).

It should be noted that the unauthorized construction refers to both a social and legal phenomenon arising at the junction of private and public interests. An example is the situation in which one civilian carries out capital construction on a land plot not belonging to him/her. In this case, on the one hand, there is an owner of a land plot, the rights to which are secured by law and for which there is a legitimate private-law interest. On the other hand, there are public interests, represented by public authorities, which regulate and control the legal relations associated with the construction of real estate objects.

Moreover, construction sites that were created without permissions of the relevant authorities, without a developed and coordinated construction project in accordance with the building and technical standards, which have not been tested in accordance with the procedure established by law, can be dangerous and harmful. Based on these characteristics, it is necessary to consider and perform an assessment of the consequences of unauthorized construction.

It should be noticed that the building can become the object of relations regulated by Art. 222 of the Civil Code only if it is recognized as being unauthorized. The unauthorized construction can be recognized if there is at least one of the four characteristics indicated in this article of the Civil Code of the Russian Federation (Figure 1). 


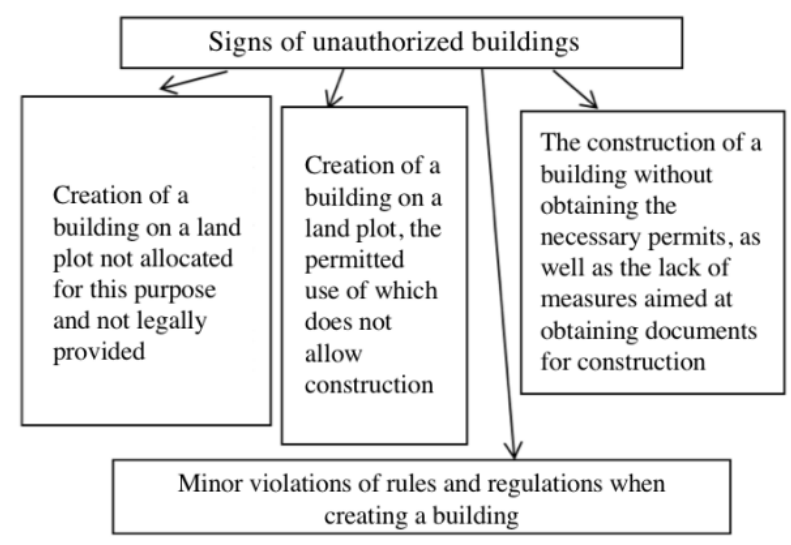

Fig. 1. Signs of unauthorized buildings.

Let us consider in more detail these features.

1. Construction of an object of capital construction on a land plot not intended for these activities and not provided for these purposes in accordance with the procedure established by law or other legal acts.

In Art. 222 of the Civil Code of the Russian Federation, the criteria for allowing the object of construction to be classified as unauthorized construction are clearly defined. One of the main criteria is the erection of a real estate object on a land plot not intended for this purpose.

Moreover, Art. 263 and 264 of the Civil Code of the Russian Federation note that only the owner of a land plot or a person who has received the owner's permission and issued a civil law transaction can carry out the construction of real estate objects on this land. Thus, the owner of an unauthorized construction can reach an appropriate legal agreement with the land owner to avoid the recognition of its construction as being unauthorized [10, 11].

2. Construction of a building on a land plot that has an authorized use different from the permit for construction of a given object on it.

Art. 263 of the Civil Code of the Russian Federation states that the owner of a land plot must comply with the requirements of not only town-planning, but building codes and rules, as well as requirements for the use of the land plot strictly for its intended purpose. At the same time, the current Russian law does not give a clear and concrete concept of the "targeted use of land," but it is often mentioned in both legal literature and law enforcement.

According to the Russian legislation, namely Part 1, Part 2, and Art. 7 of the Land Code of the Russian Federation, land resources for their designated purposes are divided into the corresponding categories. Division by category is carried out in accordance with the zoning of territories [3].

Proceeding from this, if the construction of a building on the ground does not fall into the appropriate category and is not specially allocated for these purposes, then to obtain the ownership of the object in question, it is necessary to change the purpose of the land plot, which in practice is a rather laborious task, because only with the permission of the competent authority, which is the head of the local administration and in view of the public hearings held, it would be possible to perform a change in the type of permitted use of the land.

3. Creation of an unauthorized construction without obtaining necessary permits, as well as avoidance of obtaining approvals and permits necessary for construction works.

The concept of the "building permit" is fixed in Art. 51 of the Civil Code of the Russian Federation. It is defined as a "document that confirms the compliance of the project documentation with the requirements established by the town planning regulations, the territorial planning project, and the land surveying project, in the construction, reconstruction 
of the capital construction site that is not a line facility or the requirements established by the territorial planning project and the project of land surveying, in the course of construction, reconstruction of a linear facility, and the permissibility of locating a capital construction site on a land plot in accordance with the permitted use of such land, and restrictions established in accordance with the land and other Russian legislation." [2] Only having a permission to build, a developer can work on the construction, reconstruction, and repair of buildings and structures.

The algorithm for obtaining a building permit is shown in Fig. 2.

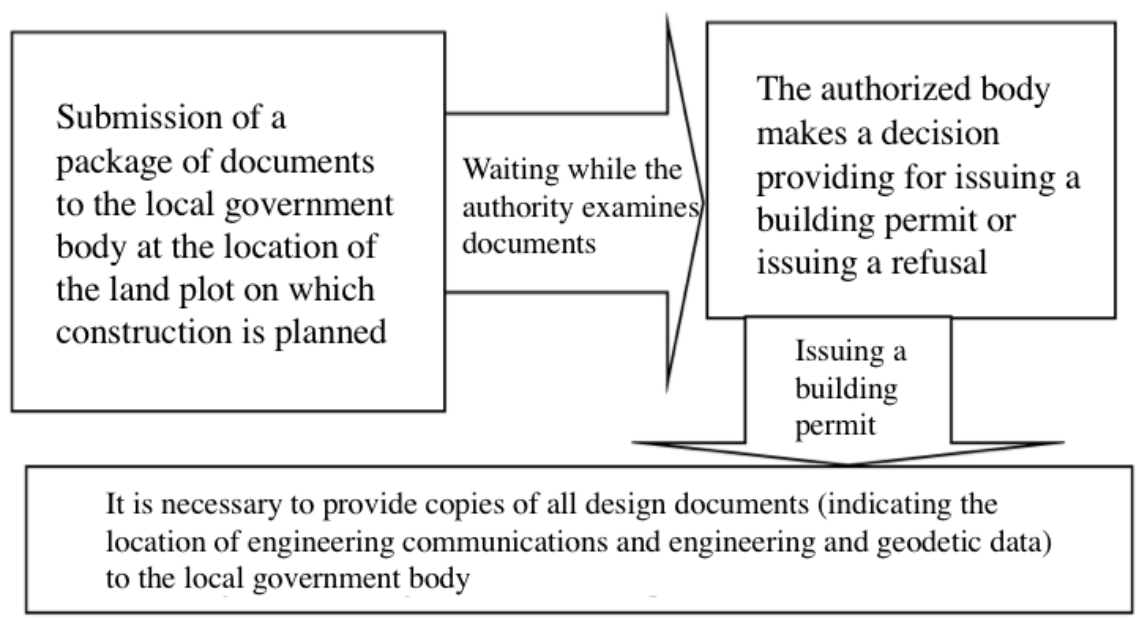

Fig. 2. Algorithm of actions for obtaining a building permit.

Construction of auxiliary structures, garages, objects that are not capital, such as stalls, awnings, and other objects, is an exception to the general list, and, according to p.17 of Art. 51 of the Civil Code, obtaining a building permit is not provided for such facilities [2].

4. Creation of an unauthorized construction with minor deviations from the code of building rules and town-planning norms.

Until September 1, 2015, only significant violations of town-planning and building codes and rules could become grounds for recognizing the building as unauthorized. After this date, there are enough minor violations to recognize the object being illegally erected.

\section{Results}

Since September 1, 2015, amendments to Art. 222 of the Civil Code (Federal Law of July 13, 2015 No. 258-FZ) have been in place. They include the following:

1) Only buildings and structures will be classified as unauthorized construction;

2) Even a slight deviation or violation of the norms will be the basis for recognizing the construction as being unauthorized;

3) The procedure for recognizing the ownership over the object of unauthorized construction will become more complicated by an order of magnitude. Moreover, the person who erected this type of construction will not have the opportunity to acquire ownership of it.

4) Local self-government bodies will be able to demolish an unauthorized structure without a court decision, if it is erected on a site that is part of the: (a) territory with special conditions for the use of areas (the exception is the zone of protection of cultural heritage); 
(b) territory of common use or in the zone of diversion of utility networks being of the federal, regional or local significance [1].

Depending on whether the person who erected the object is known, the order of actions will differ (Table 1).

Table 1. Algorithm for the demolition of the property.

\begin{tabular}{|c|c|}
\hline The developer is known & The developer is unknown \\
\hline $\begin{array}{l}\text { After the decision on the } \\
\text { demolition of an unauthorized } \\
\text { construction is taken, the local } \\
\text { government sends a copy of the } \\
\text { decision to the person who } \\
\text { erected the object within } 7 \text { days. } \\
\text { It must indicate the time for } \\
\text { demolition of the unauthorized } \\
\text { construction, which cannot } \\
\text { exceed } 12 \text { months. }\end{array}$ & $\begin{array}{l}\text { The local government is obliged within seven days } \\
\text { from the date of the decision: (a) to publish } \\
\text { information on the planned demolition of the } \\
\text { unauthorized construction site; (b) to publish } \\
\text { information about the planned demolition of an } \\
\text { unauthorized construction on the official website; (c) } \\
\text { to place a message about the planned demolition of the } \\
\text { particular unauthorized construction in form of an } \\
\text { information poster (within the boundaries of the site } \\
\text { on which the unauthorized construction site is } \\
\text { located). }\end{array}$ \\
\hline & $\begin{array}{l}\text { The local government may, at its own expense, } \\
\text { demolish an unauthorized structure. The demolition } \\
\text { period will not occur earlier than two months after the } \\
\text { day of posting the announcement of the planned } \\
\text { demolition on the official website of the local } \\
\text { government. }\end{array}$ \\
\hline
\end{tabular}

In order to avoid the recognition of an object of property being illegally constructed, it is necessary to have the following: (a) a land plot suitable for the construction; (b) a construction project that has received a positive opinion from the examination and supervisory bodies; (c) a permission to put the facility into operation (issued by a special commission in accordance with the Town Planning Code of the Russian Federation).

\section{Discussion}

The construction of unauthorized buildings has become a serious problem in the cities of most countries. Despite numerous efforts at local levels to address this problem, its existence and consequences continue to grow. Also, social, economic, and physical problems associated with this situation are increasing day by day, negatively affecting the development of a comfortable urban environment [14]. Self-constructed buildings do not allow creating a reliable and accurate database of real estate objects, which is necessary for monitoring, analysis, and forecasts. In addition, there is a huge loss of income from property tax resulting from an inaccurate database of real estate.

Self-built neighborhoods or illegally chopped plots are often found on the outskirts of cities in South-Eastern Europe, from Serbia and Bosnia and Herzegovina to Greece. The number of illegal buildings being built in Turkey's three largest cities (Istanbul, Ankara, Izmir) is estimated at approximately 2 million $[15,16]$.

An unexpected discovery was made in 2012 by specialists of the National Cadastral Agency of Italy. They compared the images received from the satellite with official documents and found out that some houses around Naples, Cosenza, Salerno, and Reggio di Calabria were built illegally. Due to the concealment of this property, according to the Ministry of Finance of Italy, the state did not receive 472 million euros in taxes. [13]. At the same time, it should be noted that the European practice provides for mechanisms for 
compensation for the demolition of illegally erected buildings, while in the Russian legal system it is only necessary to develop and implement them.

The most stringent measures against erecting illegal buildings are taking place in Europe. For example, in the UK, no court decision is required for forced dismantling if illegal buildings or their redevelopment appear on the land.

Active struggle against illegal building is conducted not only in Europe. For example, in Israel, in July 2015, the army conducted an operation to eliminate unauthorized buildings in the West Bank, in the village of Beit El.

According to the Ministry of Construction and Housing and Communal Services of the Russian Federation, the problem of unauthorized construction has recently become of a threatening scale.

As of 2017, unauthorized construction is widely spread in almost all cities of Russia, one of the resonant developments in the field of real estate over the past few years is the demolition of trading pavilions in Moscow, being recognized as objects of unauthorized construction. The Irkutsk region is no exception (Figure 3).

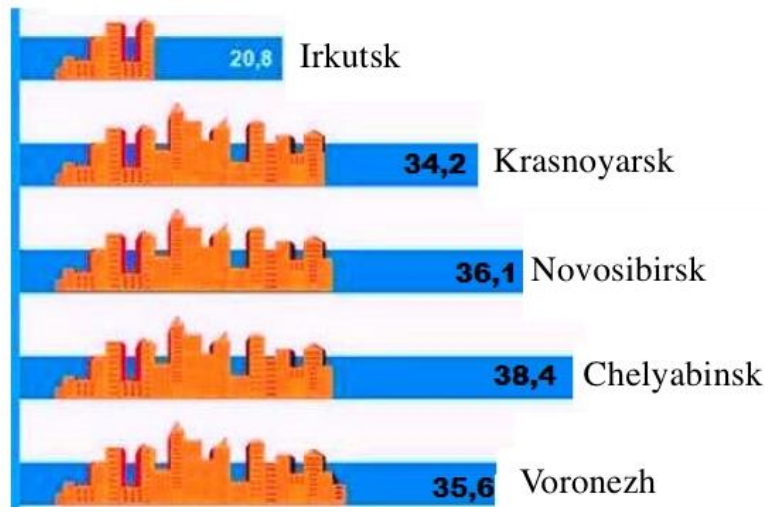

Fig. 3. Unauthorized construction, according to data published on official websites of the cities represented.

In accordance with paragraph 4.2 of the Protocol of the meeting of the Government of the Irkutsk Region (dated 04.02.2016), the State Construction Supervision Service of the Irkutsk region maintains the Register of Unified Recording of Unauthorized Buildings Identified on the Territory of the Irkutsk Region. This register includes 2 main sections:

1) Unauthorized buildings, during construction, reconstruction of which state construction supervision should be carried out;

2) Unauthorized buildings, during construction, reconstruction of which state construction supervision should not be carried out [5].

When studying jurisprudence, on the issue of legalization of the ownership of illegally erected construction in Irkutsk, it was revealed that the special distribution in 2016-2017 got disputes concerning arbitrarily erected objects of commercial purpose (Figure 4). 


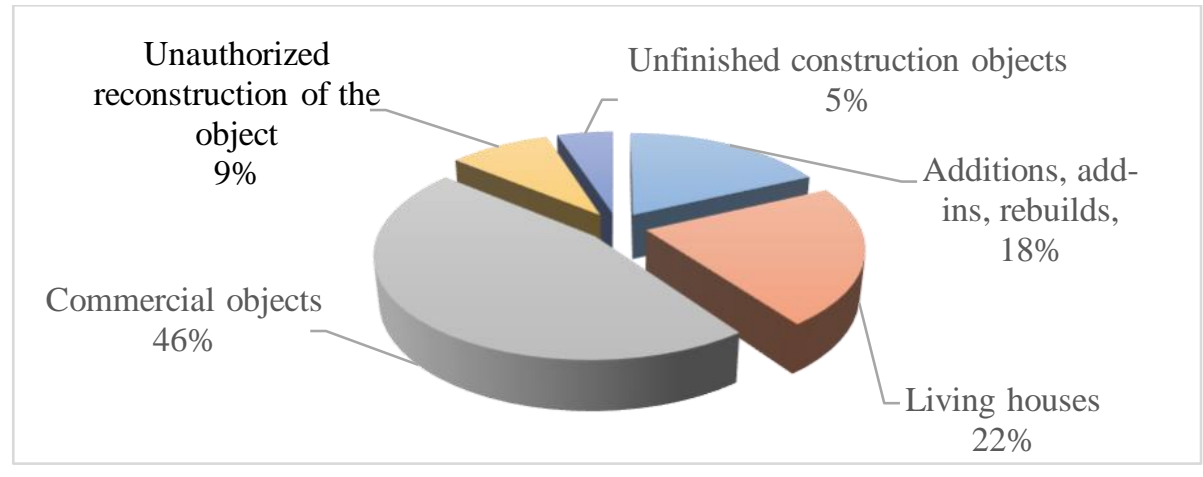

Fig. 4. Kinds of objects built arbitrarily in Irkutsk, 2016-2017 [5].

First of all, this tendency towards the growth of unauthorized commercial facilities is explained by the fact that it is difficult to obtain the necessary documentation for the construction, especially during the construction of various commercial facilities. This process can drag on with time, so developers often decide to come to such an exit: they begin collecting permits while building [17]. Such an object is to be considered illegal until the moment when all documents are collected.

On the basis of the data given, an analysis was made of information on the fate of unauthorized buildings, according to which, in 55\% of cases, the court decides to recognize the ownership of the object, while in $45 \%$ of the cases, it decides to demolish the object.

\section{Acknowledging property rights}

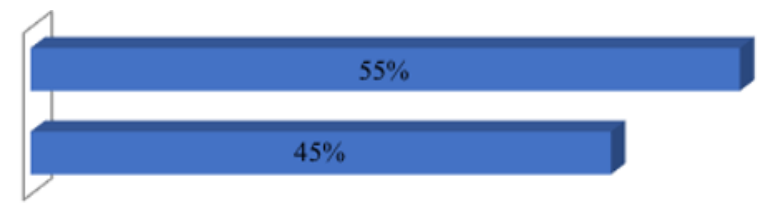

Fig. 5. Options for further development of events on the self-constructed commercial objects.

On the basis of the diagram above, we should agree with a number of authors who argue that demolition decisions are made on the grounds that the objects are investigated incorrectly or incompletely within the framework of the expertise and are misleading.

\section{Conclusion}

Legislation in the field of legal regulation of objects related to unauthorized erection is in constant improvement. The Government of the Russian Federation has submitted to the State Duma a draft of the Ministry of Construction of Russia, which regulates issues related to the recognition of buildings by unauthorized structures and their demolition. According to this bill, the object that has been built would probably not be demolished in case if the owner has all necessary approvals and decisions. To date, the documents have been approved by the State Duma Committee on State Construction and Legislation.

The Ministry of Construction of Russia proposed to legalize the term "unauthorized construction". They define it in the following way: "A building erected on a land plot provided illegally or on a site whose construction permit does not allow the erection of this object." Self-construction is also recognized as the buildings being "created without obtaining necessary permits or with violation of town-planning and building norms and rules."

Following the example of Italy, the state authorities in the Moscow region are currently 
carrying out aerial photography of real estate objects and comparing the identified objects with the real property register. Further, the state bodies themselves will put the object on the register. Moreover, the program "Mass demolition of distressed real estate" started in 2016. Lately, the probability of demolition of the self-constructed objects has increased significantly $y$.

\section{References}

1. The Civil Code of the Russian Federation (Civil Code) of November 30, 1994 N 51-FZ (as amended on December 29, 2017 N 459-FZ) (Consultant Plus, Moscow, 2018); Urban Development Code of the Russian Federation of 29.12.2004 N 190-FZ (as amended on December 31, 2017 N 506-FZ, N 507-FZ) (Consultant Plus, Moscow, 2018)

2. The Land Code of the Russian Federation of October 25, 2001 N 136-FZ (as amended on December 31, 2017, N 506-FZ, N 507-FZ) (Consultant Plus, Moscow, 2018)

3. The definition of the Supreme Court of the Russian Federation of September 30, 2014 $N$ 4-KG14 18: Definition of the Supreme Court of the Russian Federation from 09.09.2014 N18-KG14-97, etc. (Consultant Plus, Moscow, 2018)

4. Unauthorized construction: the register of unified accounting of unauthorized buildings identified on the territory of the Irkutsk region as of 01/01/2018 (http://irkobl.ru/sites/stroynadzor/OSTOROGNO/samovol\%21.php, 2013)

5. V. A. Vlasenko, Society and Law, 2, 267-271 (2010)

6. K. S. Gultyaev, Abstracts of the Scientific Round Table "Legal problems of unauthorized construction," 8 (2016)

7. A. N. Latiev, Legal problems of unauthorized construction, 7 (2016)

8. L. A. Motlohova, Economics and Law, 6 (64), 40-43 (2016)

9. S. Popov, Your Partner-Consultant, 34 (9600), (2015)

10. L.V. Shchennikova, Legislation, 3, 18-22 (2009)

11. A. Goncharov, Land and Real Estate of Siberia, 4 (18), 34-35 (2009)

12. To the foundation, and then ... How the world's countries are fighting the selfconstruction (https://lenta.ru/articles/2016/02/22/samostroi/, 2016)

13. Y. V. Ragulina, A. V. Bogoviz, A. N. Alekseev, Advances in Intelligent Systems and Computing, 622, 568-573 (2018)

14. Ö. Korkmaz, General overview, economic and social analysis, 46, 15, (2013)

15. European Construction Monitor, 24, 15, (2016)

16. M. Y. Veselovsky, M. A. Izmailova, A. V. Bogoviz, S. V. Lobova, A. N. Alekseev, Quality - Access to Success, 19(162), 60-66 (2018) 